\title{
Factor V Kuwait: A Novel Mutation in the Coagulation Factor V Gene Discovered in Kuwait
}

\author{
Mehrez M. Jadaon Ali A. Dashti Hend L. Lewis \\ Department of Medical Laboratory Sciences, Faculty of Allied Health Sciences, Kuwait University, Kuwait
}

\section{Key Words}

Factor V Kuwait • Venous thromboembolic disorder . Restriction fragment length polymorphism

\begin{abstract}
Objective: It was the aim of this study to report a new point mutation in the clotting factor $\mathrm{V}$ gene in the general Arab population. Subjects and Methods: The HR2 haplotype was tested in 288 Arabs living in Kuwait - 188 patients with venous thromboembolic disorders (VTE) and 100 healthy subjects - using polymerase chain reaction and restriction fragment length polymorphism techniques. The presence of the new mutation was verified by DNA sequencing. Results: Two (1.06\%) VTE patients had guanine instead of the wild-type adenine at nucleotide number 3935 (A3935G) of the factor $V$ gene. This mutation caused a histidine to arginine change in amino acid number 1254 of the factor $V$ molecule. The new mutation is termed 'factor V Kuwait' (His1254Arg) and was absent in the 100 healthy subjects. Conclusion: It appears that factor $\mathrm{V}$ Kuwait could be a risk factor for developing VTE in Arabs. A larger study is needed to confirm this observation.
\end{abstract}

Copyright (C) 2006 S. Karger AG, Basel

\section{Introduction}

Normal haemostasis is a balanced system which, on the one hand, prevents excessive bleeding from the site of injury while, on the other hand, it maintains blood circulation by inhibiting intravascular coagulation. Therefore, an effective haemostatic process possesses an intrinsic well-balanced regulatory system involving a number of dynamic mechanisms and chemical and physical reactions. Blood coagulation is one of these dynamic systems, in which a prominent response to an injury is recruited in the form of a series of stepwise (cascading) interactions leading to fibrin formation. This complex system involves certain proteins referred to as plasma clotting factors [1]. Among these clotting factors, factors V and VIII have enormous potential as cofactors in accelerating the activation of clotting factors $\mathrm{X}$ and prothrombin (factor II), respectively [2]. Factors V and VIII are high-molecularweight glycoproteins (300-330 kDa) and are synthesized in the liver as single-chain precursors [3, 4]. Genetically, the factor $\mathrm{V}$ gene is present in chromosome 1q21-25, spanning more than 80,000 nucleotide bases containing 25 exons. The full nucleotide sequence of the cDNA of the factor $\mathrm{V}$ gene has been determined [5]. Many studies have reported cases with different point mutations at different positions in the cDNA of the factor V gene, some of which were only silent polymorphism, while a few

\begin{tabular}{ll}
\hline KARGER & ( ) 2006 S. Karger AG, Basel \\
1011-7571/06/0152-0102\$23.50/0 \\
$\begin{array}{l}\text { Fax +4161306 } 1234 \\
\begin{array}{l}\text { E-Mail karger@karger.ch } \\
\text { www.karger.com }\end{array}\end{array}$ & $\begin{array}{l}\text { Accessible online at: } \\
\text { www.karger.com/mpp }\end{array}$
\end{tabular}


caused amino acid replacement. Factor V Leiden (G1691A; Arg506Gln) may be the most important missense point mutation in the factor $\mathrm{V}$ gene due to its established association with venous thromboembolic disorders (VTE), with a high 3- to 10-fold risk in heterozygotes and a 30- to 140-fold risk in homozygotes [6-9]. HR2 haplotype, which consists of 12 highly associated polymorphisms in the factor $\mathrm{V}$ gene, has been studied lately as another possible risk factor for developing VTE [10, 11]. This haplotype has been the subject of the latest research by the authors of this article, examining the prevalence and possible risk of HR2 haplotype in the Arab population and patients with VTE living in Kuwait [12]. While testing for HR2 haplotype, an unexpected observation was obtained in 2 of the patients. Therefore, we investigated this observation in order to identify a new missense point mutation in the factor $\mathrm{V}$ gene.

\section{Subjects and Methods}

Two hundred and eighty-eight subjects, 188 patients with VTE and 100 age- and sex-matched healthy individuals, all of Arab ethnicity and living in Kuwait, were tested for the HR2 haplotype, using polymerase chain reaction (PCR) and restriction fragment length polymorphism (RFLP) techniques according to Lunghi et al. [10]. A full description of the above techniques has been given previously [12]. Briefly, venous blood was collected from each subject, and DNA was extracted and purified using the conventional phenol-chloroform method. For each DNA sample, PCR was performed using the following two primers: forward primer 5'-C AAG TCC TTC CCC ACA GAT ATA-3'; reverse primer 5'-AG ATC TGC AAA GAG GGG CAT-3'. These primers flank a DNA fragment of 703 base pairs (bp), from nucleotide number 3579 to nucleotide number 4281 of the factor $\mathrm{V}$ gene. This fragment contains the R1/R2 polymorphism site (A4070G), which is one of the polymorphisms of HR2 haplotypes. Following the PCR procedure, the DNA fragments were subjected to cutting using the $R s a$ I restriction enzyme, and finally, the fragments were separated by gel electrophoresis, stained with ethidium bromide, and visualized under the UV light.

\section{Results}

The results of PCR/RFLP in 186 VTE patients and 100 normal subjects revealed the amplification of 703-bp DNA fragments, which were cut by the $R s a$ I restriction enzyme into 492- and 211-bp fragments. Only 2 VTE cases gave unexpected results. The 703-bp fragments in these 2 cases were cut into two fragments with an estimated size of $350 \mathrm{bp}$ (fig. 1). Accordingly, this suggested a possible presence of a newly created restriction site for

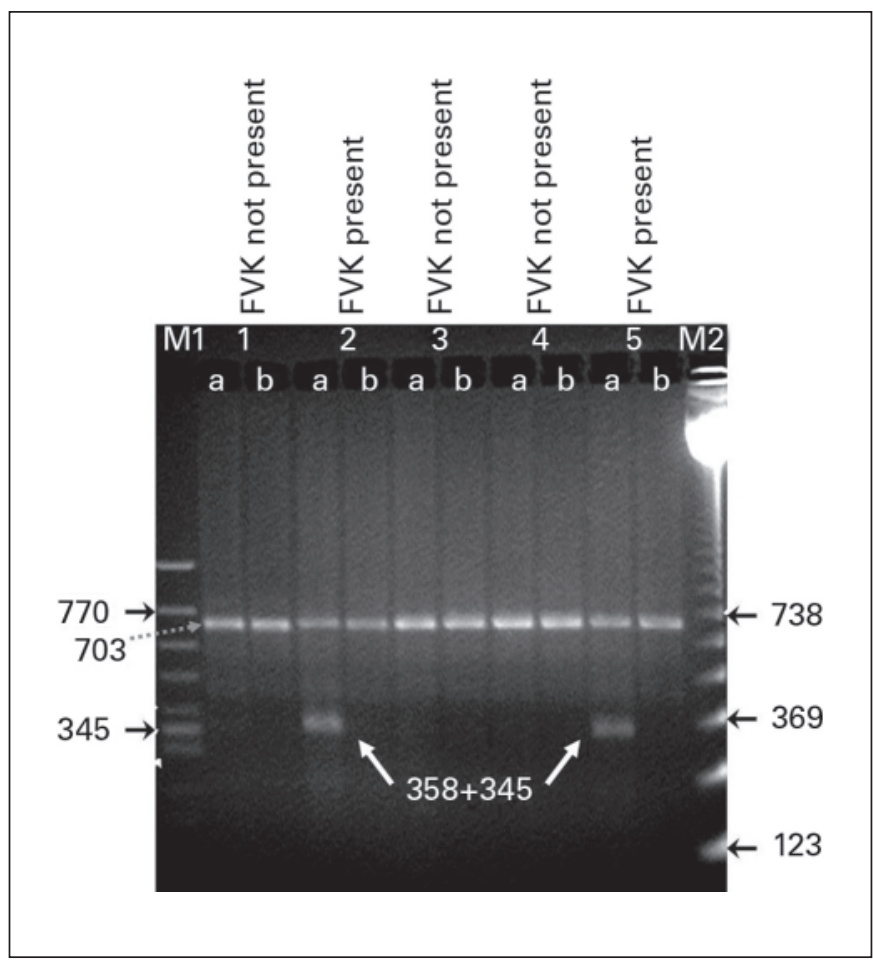

Fig. 1. Agarose gel electrophoresis showing the 703-bp PCR amplicons before (b) and after (a) cutting with $R s a$ I restriction enzyme in 5 cases (1-5). Cases 2 and 5 had 358- and 345-bp fragments after cutting with $R s a$ I enzyme, which indicated the presence of the new factor V Kuwait mutation (FVK). Cases 1, 3 and 4 did not show the above cutting pattern, and thus did not have the new mutation. $\mathrm{M} 1$ and $\mathrm{M} 2$ are DNA markers.

the $R s a$ I enzyme, somewhere in the middle of the 703-bp fragment, thus cutting it into two halves. A review of the DNA sequence of the factor $\mathrm{V}$ gene revealed a potential restriction site for the Rsa I enzyme starting at nucleotide 3935, with the sequence ATAC. The restriction sequence for the $R s a$ I enzyme is GTAC, and thus a possible point mutation at nucleotide 3935 (adenine to guanine) could create a restriction site for the Rsa I enzyme. This was confirmed by DNA sequencing for the 2 suspected cases using the dideoxy-mediated chain termination technique, and both cases were found to have the expected mutation. Consequently, a new restriction site was created for the Rsa I enzyme, which cut the 703-bp fragment into 358and $345-b p$ fragments. These two bands were very close to each other and were shown as one band on agarose gel electrophoresis (fig. 1). This new missense point mutation caused a histidine to arginine change in the amino acid number 1254 in the factor $\mathrm{V}$ molecule (His1254Arg) which we have termed 'factor V Kuwait'. 


\section{Discussion}

Blood coagulation is a very efficient haemostatic process involving many factors and cofactors, which function in a very organized manner under full control to prevent bleeding from sites of injury [1]. Many genetic and acquired abnormalities can affect the clotting factors, which would result in bleeding tendencies or the development of VTE, as exemplified by factor V Leiden (G1691A; Arg506Gln), which is believed to cause VTE in carriers [6-9]. Another important example is the HR2 haplotype, which consists of a group of associated polymorphisms in the factor $\mathrm{V}$ gene and has been reported to be associated with VTE, although this is still uncertain $[10,11]$. Other rare mutations in the factor $\mathrm{V}$ gene were also reported, such as factor V Liverpool (Ile359Thr) [13, 14], factor V Cambridge (Arg306Thr) [15], and factor V Hong Kong (Arg306Gly) [16], which have an additional effect in causing VTE.

In this study, a new missense point mutation in the clotting factor $\mathrm{V}$ gene was identified, where an adenine nucleotide was replaced by a guanine nucleotide at nucleotide position 3935 of the factor $V$ gene sequence (A3935G; factor V Kuwait mutation). Factor V Kuwait mutation caused a change from histidine to arginine in the amino acid number 1254 of the translated factor $\mathrm{V}$ molecule (His 1254Arg). Since changes in the amino acid sequence of proteins can cause changes in their functions, this newly discovered mutation may cause an adverse impact on the function of factor $\mathrm{V}$, or it may simply have no effect. It is still not possible to estimate the consequences of this mutation in the absence of a proper knowledge of the possible effects of the above changes in amino acids.
The factor V Kuwait mutation was found to be present in 2 out of 188 VTE patients, and equally important, it was absent in the 100 normal controls. This may suggest a possible risk factor for developing VTE in carriers of this mutation. Moreover, in both cases, 1 patient had antithrombin deficiency, while the other was heterozygous for the factor V Leiden mutation. Both defects are known risk factors for VTE. It is therefore tempting to postulate that factor V Kuwait might have added to the risk of developing VTE in these 2 patients, especially since it is widely accepted that VTE disorders usually need coexistence of more than one risk factor to clinically manifest themselves. However, a larger prospective study is required to confirm any relationship between factor $\mathrm{V} \mathrm{Ku}$ wait and VTE.

This new mutation has been submitted to the GenBank and registered with the accession number AY881018.

\section{Conclusion}

The factor V Kuwait mutation, found in Arabs with VTE, is a new entity in the pool of genetic abnormalities of the clotting factor $\mathrm{V}$.

\section{Acknowledgement}

The authors are grateful to the General Facilities Laboratories (project number GM01/01), Faculty of Medicine, Kuwait University, for performing DNA sequencing for this study.

\section{References}

1 Davie EW: Biochemical and molecular aspects of the coagulation cascade. Thromb Haemost 1995;74:1-6.

2 Kane WH, Davie EW: Blood coagulation factor V and VIII: structural and functional similarities and their relationship to hemorrhagic and thrombotic disorders. Blood 1988; 71: 539-555.

3 Walker FJ, Fay PJ: Regulation of blood coagulation by the protein C system. FASEB J 1922; 6:2561-2567.

- 4 Cox MJ, Rees DC, Martinson JJ, Clegg JB: Evidence of a single origin of factor $\mathrm{V}$ Leiden. Br J Haematol 1996;92:1022-1025.
-5 Jenny RJ, Pittman DD, Toole JJ, Kriz RW, Aldape RA, Hewick RM, Kaufman RJ, Mann KG: Complete cDNA and derived amino acid sequence of human factor V. Proc Natl Acad Sci USA 1987;84:4846-4850.

66 Dahlbäck B, Carlsson M, Svensson PJ: Familial thrombophilia due to a previously unrecognized mechanism characterized by poor anticoagulant response to activated protein $\mathrm{C}$ : prediction of a cofactor to activated protein $\mathrm{C}$. Proc Natl Acad Sci USA 1993;90:1004-1008

7 Bertina RM, Koeleman BPC, Koster T, Rosendaal FR, Dirven RJ, de Ronde HD, van der Velden PA, Reitsma PH: Mutation in blood coagulation factor $\mathrm{V}$ associated with resistance to activated protein C. Nature 1994; 369:64-67.
8 Dahlbäck B: Resistance to activated protein C caused by the factor V R506Q mutation is a common risk factor for venous thrombosis. Thromb Haemost 1997;78:483-488.

-9 Faioni EM, Razzari C, Martinelli I, Panzeri D, Franchi F, Mannucci PM: Resistance to activated protein $\mathrm{C}$ in unselected patients with arterial and venous thrombosis. Am J Hematol 1997;55:59-64.

10 Lunghi B, Lacoviello L, Gemmati D, Dilasio MG, Castoldi E, Pinotti M, Castaman G, Redaelli R, Mariani G, Marchetti G, Bernardi F: Detection of new polymorphic markers in the factor $\mathrm{V}$ gene: association with factor $\mathrm{V}$ levels in plasma. Thromb Haemost 1996;75:45-48. 
11 Alhenc-Gelas M, Nicaud V, Gandrille S, van Dreden P, Amiral J, Aubry ML, Fiessinger JN Emmerich J, Aiach M: The factor V gene A4070G mutation and the risk of venous thrombosis. Thromb Haemost 1999;81:193197.

12 Jadaon MM, Dashti AA-R: HR2 haplotype in Arab population and patients with venous thrombosis in Kuwait. J Thromb Haemost 2005;3:1467-1471.
13 Mumford AD, McVey JH, Morse CV, Gomez $\mathrm{K}$, Steen M, Norstrom EA, Tuddenham EGD, Dahlbäck B, Bolton-Maggs PHB: Factor V I359T: a novel mutation associated with thrombosis and resistance to activated protein C. Brit J Haematol 2003;123:496-501.

14 Steen M, Norstrom EA, Tholander AL, BoltonMaggs PHB, Mumford A, McVey JH, Tuddenham, EGD, Dahlbäck B: Functional characterization of factor V-Ile359-to-Thr: a novel mutation associated with thrombosis. Blood 2004;103:3381-3387.
5 Williamson D, Brown K, Luddington R, Baglin C, Baglin T: Factor V Cambridge: a new mutation (arg306-to-thr) associated with resistance to activated protein C. Blood 1998;91: 1140-1144

16 Norstrom E, Thorelli E, Dahlback B: Functional characterization of recombinant FV Hong Kong and FV Cambridge. Blood 2002;100: 524-530. 